\title{
Plant location as a function of the standard of maintenance efficiency: An empirical perspective
}

\author{
P.N. Palmer \\ Department of Business Economics, University of South Africa, Pretoria
}

In this article, aspects relating to the management of the maintenance function within a production system are discuss. ed. Inordinate disparities undermining the execution of the maintenance function - as a result of inter-regional differences regarding the availability of maintenance skills are identified on the basis of empirical evidence and with the aid of inferential statistics. The cause/effect impact that such disparities have on the maintenance of equipment in a plant are singled out, and the reasons therefore discussed, while the comparative, inter-regional differences referred to stem from the tenets of industrial centralization versus industrial decentralization. The locales affected are the Johannesburg economic region as opposed to the economic growth point of Babelegi, in the Republic of Bophuthatswana. In conclusion, certain observations and recommendations are postulated with a view to highlighting the impact of locational differences on both the efficiency and effectiveness with which the maintenance function can be executed.

S. Afr. J. Bus. Mgmt. 1981, 12: 60-63

In hierdie artikel word sekere aspekte wat op die bestuur van die onderhoudsfunksie betrekking het, bespreek.

Buitengewone teenstrydighede wat die uitvoering van die onderhoudsfunksie ondermyn - as gevolg van interstreekse verskille sover dit die beskikbaarheid van onderhoudsvaardighede betref - word geïdentifiseer op die basis van empiriese getuienis en met behulp van afgeleide statistiek. Die oorsaak/gevolg impak wat sulke teenstrydighede op die onderhoud van toerusting in ' $n$ aanleg het, word uitgesonder en die redes daarvoor word bespreek, terwyl verwys word na die vergelykende, interstreekse verskille wat vanuit die beginsel van industriële sentralisasie teenoor industriële desentralisasie voortspruit. Die gebiede wat geaffekteer word is die Johannesburg ekonomiese streek teenoor die ekonomiese groeipunt van Babelegi in die Republiek van Bophuthatswana. Ten slotte word sekere waarnemings en aanbevelings gemaak ten einde die impak van liggingsverskille op die doeltreffendheid sowel as die effektiwiteit waarmee die onderhoudsfunksie uitgevoer kan word, uit te lig. S.Afr. Tydskr. Bedryfsl. 1981, 12: 60-63
Whilst it would be a trite assertion to contend that the effective operation of any production system is dependent upon the maintenance of all parts of the system, yet, the dearth of effective maintenance invariably has a deleterious effect on the performance of production equipment in a plant.

The practical corollary to this is that the efficiency with which the maintenance function is capable of being executed depends on the availability of appropriate skills. Apart from being readily available, such skills need to be commensurately susceptible to continuous training with a view to maintaining and improving its level of competence. The timeous availability of maintenance skills does, therefore, augur well for manufacturers who are in the fortunate position of having ready access to this indispensable collection of skills. 'Indispensable' in the sense that they signify the performance of an essential function by maintenance staff who ensure the smooth operation of the production facilities in a factory.

Although it is conceded that the responsibility for minor, routine maintenance of equipment rests with the operator, on account of its rudimentariness, frequently the technical complexities of sophisticated equipment warrants advanced inspection - quite apart from the normal preventive maintenance - to be performed by maintenance personnel with the commensurate skills. The local availability of such specialized maintenance skills holds distinct advantages for the manufacturer while the immediate availability of such skills right on the factory premises - where justified - must be seen as the ideal arrangement. Where feasible, such an arrangement is to be preferred to recruiting the services of the representatives of the equipment with the concomitant expenses involved. This preference is valid, even where there is a guarantee on the equipment.

To many, the question of the adequate availability of suitably qualified maintenance staff may appear to be a moot one. However, to manufacturers who do not enjoy the industrial sophistication of South Africa's conurbations, with their commensurate supply of specialized skills, the question is fraught with practical realities. This appears to be true of manufacturers who have either located or translocated their manufacturing operations to a 'border' industrial area or more particularly, to an economic growth point within one or more of the national states adjacent to or within the boundaries of 
South Africa in response to government inducements to do so. This is consonant with the government's policy on industrial decentralization. For those manufacturers operating in these 'decentralized regions' the implications of an inadequate supply of maintenance skills is serious. Indeed, it goes without saying that a dearth of suitably skilled maintenance staff invariably contributes to machine breakdowns or failures and the production losses which ensue.

Empirical evidence in support of this observation was evinced by the writer during the course of a recent comparative survey conducted among manufacturers located at the economic growth point of Babelegi in the Republic of Bophuthatswana.

The comparativeness of this survey stems from its inter-regional nature, inasmuch as a randomly stratified sample of manufacturers located at Babelegi and the Johannesburg economic region respectively were subjected to a matched paired comparison on a one-to-one basis. This means that an equal number of participants in each region were selected according to the following criteria:

- similarity of Standard Industrial Classification of economic activities, in this instance, restricting the comparison to a sample of manufacturers who manufacture fabricated metal products, machinery and equipment, and

- similarity of Employment Group Classification.

The use of the Standard Industrial Classification was deemed to be justified on the grounds that it is a classification by type of economic activity rather than by ownership; type of enterprize; organizational structure; degree of mechanization; size of production unit in respect of turnover and capital or labour. According to the Standard Industrial Classification, the main activity of the manufacturing establishment is to be judged in terms of products or services rendered. These represent its economic activity which is the basis for classification. On the other hand, comparisons according to parallel Employment Group Classifications restricted the survey to an inter-firm comparison in terms of parity of number of employees employed. In this way an effort was made to purify the matched paired comparison on the basis of equal criteria.

With the aid of inferential statistics the writer attempted to establish whether or not a statistically significant relationship could be found to exist between the geographical location of the participant manufacturers (constituting the independent variable in this survey) and the dependent variables being investigated, in this case, the variable relating to the availability of skilled maintenance staff in the respective geographical regions.

Table 1, representing a multiple contingency table, indicates the frequency distribution of responses to this variable - on an inter-regional basis - with column 1 reflecting the affirmative responses regarding the availability of skilled maintenance staff and column 2 reflecting the negative responses, while column 3 reflects the percentage difference on the part of respondents as to the availability or non-availability of skilled maintenance staff. A cursory glance at these frequency distributions reveals a significantly affirmative response
Table 1 Multiple contingency table

\begin{tabular}{|c|c|c|c|c|c|}
\hline & $\begin{array}{c}\text { Count } \\
\text { Row PCT } \\
\text { Col PCT } \\
\text { Tot PCT }\end{array}$ & 1 & $\begin{array}{c}\text { MNTCE4 } \\
2\end{array}$ & 3 & $\begin{array}{l}\text { Row } \\
\text { Total }\end{array}$ \\
\hline \multirow[t]{4}{*}{ Region } & 1 & 16 & 3 & 1 & 20 \\
\hline & & 80,0 & 15,0 & 5.0 & 50,0 \\
\hline & & 84,2 & 16,7 & 33,3 & \\
\hline & & 40,0 & 7,5 & 2,5 & \\
\hline \multirow[t]{6}{*}{ Region } & 2 & 3 & 15 & 2 & 20 \\
\hline & & 15,0 & 75.0 & 10,0 & 50,0 \\
\hline & & 15,8 & 83,3 & 66,7 & \\
\hline & & 7,5 & 37,5 & 5.0 & \\
\hline & Column & 19 & 18 & 3 & 40 \\
\hline & Total & 47.5 & 45,0 & 7,5 & 100,0 \\
\hline
\end{tabular}

Chi Square $=17,22807$ with 2 degrees of freedom

Significance $=0,0002$.

by respondents in Region 1 (representing the Johannesburg economic region) in comparison to the significantly negative response elicited from respondents in Region 2 (representing Babelegi). The distribution of these responses points to a statistically significant relationship between the geographical location of a manufacturing establishment and the corresponding availability of skilled maintenance staff. It does not, however, indicate the strength of the relationship neither the precise causes thereof.

Table 2 provides corroborative statistical evidence of the magnitude of the statistically assymetrical relationship between the independent variable, namely, geographical location, and the dependent variable, namely, the availability of maintenance skills, inasmuch as it reveals the degree of confidence with which the hypothesis, on which this empirical research was based, could be affirmed. This is borne out by the probability values $(0,0000)$ obtained for this variable. In so doing it confirms the contention that the geographical location of a manufacturing establishment influences the ability with which suitable maintenance skills can be recruited.

The consequence of this inter-regional disparity is multifarious, pointing to numerous discrepancies between manufacturers situated in the Johannesburg economic region (Region 1) and their counterparts situated in Babelegi (Region 2), with the latter being locationally disadvantaged in so far as their accessibility to maintenance skills is concerned. Empirically established disparities caused by the absence of skilled maintenance staff in Babelegi results, inter alia, in:

- the incurrence of production idle time with attendant losses on account of the disruption which such skill shortages precipitate;

- inordinate machine set-up costs on account of irregular maintenance of machines;

- the erratic utilization of personnel and plant capacity;

all of which proved to be some of the main factors militating against attempts to maximize the performance and reliability of production equipment in plants. 
Table 2 t Test results for MNTCE 4

\begin{tabular}{|c|c|c|c|c|c|c|c|}
\hline & & $\begin{array}{l}\text { Number of } \\
\text { cases }\end{array}$ & \multicolumn{2}{|c|}{ Mean } & $\begin{array}{l}\text { Standard } \\
\text { deviation }\end{array}$ & \multicolumn{2}{|c|}{$\begin{array}{l}\text { Standard } \\
\text { error }\end{array}$} \\
\hline Group 1 & & 20 & \multicolumn{2}{|c|}{1,2500} & 0,550 & \multicolumn{2}{|r|}{0,123} \\
\hline Group 2 & & 20 & \multicolumn{2}{|c|}{1,9500} & 0,510 & \multicolumn{2}{|r|}{0,114} \\
\hline & & \multicolumn{3}{|c|}{$\begin{array}{c}\text { (Pooled variance } \\
\text { estimate) }\end{array}$} & \multicolumn{3}{|c|}{$\begin{array}{c}\text { (Separate variance } \\
\text { estimate) }\end{array}$} \\
\hline F value & $\begin{array}{l}\text { 2-tail } \\
\text { PROB }\end{array}$ & \multicolumn{2}{|r|}{$\begin{array}{c}\text { Degrees } \\
\text { of } \\
\text { freedom }\end{array}$} & $\begin{array}{l}\text { 2-tail } \\
\text { PROB }\end{array}$ & \multicolumn{2}{|r|}{$\begin{array}{l}\text { Degrees } \\
\text { of } \\
\text { freedom }\end{array}$} & $\begin{array}{c}\text { 2-tail } \\
\text { PROB }\end{array}$ \\
\hline 1,16 & 0,747 & $-4,17$ & 38 & 0,000 & $-4,17$ & 37,79 & 0,000 \\
\hline
\end{tabular}

Analogous to the afore-mentioned are some of the reasons - identified by the writer - for the apparent shortage of maintenance skills in Babelegi, some of which are axiomatic, namely:

- The location of Babelegi, relative to the supply of skilled maintenance personnel who are concentrated in the Pretoria-Witwatersrand-Vereeniging region which accounts for what may well be perceived as a regular, intermittent shortage of these skills.

- The empirically established diversity of maintenance needs in the region, which can be accounted for by the uniqueness and wide-ranging sophistication of the machinery and equipment currently in usage in Babelegi. This is due to the numerous manufacturers represented in Babelegi (some eighty-seven at the time this research was conducted) manufacturing a wide-range of finished products which necessitate the utilization of a diversity of machines and equipment, the maintenance of which calls for differing degrees of skills. The extent of the diversity has resulted in the need for a wide-range of local maintenance skills, not all of which can be internally supplied by manufacturers operating in Babelegi. This has been indicated by the probability value $(0,0000)$ - see Table 2 - dealing with the availability of maintenance staff in this region. Indeed, such a dearth of maintenance skills indicates that localized manufacturing operations in Babelegi should be as versatile as a plant's capacity and personnel permit. Consequently, the degree of versatility would be an indication of the extent to which manufacturers would be able to avoid relying on imported maintenance skills, an excessive necessity of which would discourage manufacturers from decentralizing their operations to Babelegi.

- Inadequate training facilities which serves to exacerbate existing skill shortages among indigenous members of the labour force (on account of their low skill threshold) together with the poor standard of training among local operators.

- Inadequate government concessions with particular reference to the maintenance skill requirements in Babelegi. This is borne out by the probability values obtained for the allied variables relating to the degree of state intervention deemed desirable on the part of respondents. Inherent in these responses was a trade-off between state intervention in the form of the provision of a maintenance pool system to meet the maintenance needs of Babelegi or the provision of additional and specific concessionary incentives designed to alleviate the maintenance skill shortages being experienced.

- The lack of adequate, let alone congenial, infrastructural facilities both in the industrial area of Babelegi and the adjacent residential area of Hammanskraal, constitutes a disincentive to the recruitment and retention of skilled maintenance personnel.

Effectively, the impact of perpetual maintenance skill shortages - albeit temporarily - must, it is contended, have a pervasive influence on the productivity of manufacturing operations, some of which are noted below:

Firstly, it inevitably results in the incurrence of inordinate incremental costs affecting the operating cost structure of manufacturing establishments, owing to unforeseeable delays in the execution of more advanced maintenance work. This is because allowances have to be made for the importation of outside skills to supplement internal maintenance operations. Secondly, delays in the execution of maintenance complicates the determination of pragmatically realistic production lead times. Customer relations and, ultimately, the goodwill of the manufacturing establishment/enterprise could be at stake if this state of affairs persists. Thirdly, production planning for throughput times is complicated, leading to the establishment of incongruous planning horizons in order to overcome this anomaly. Finally, the persistence of maintenance skill shortages leads to erratic machine downtimes and a lowering of employee productivity. The reinstatement of plant and personnel at required output rates is frequently costly.

In essence, the empirical observations cited in this article purport to crystallize but one of the constellation of variables confronting any manufacturer contemplating regional decentralization. Regardless of the variables under consideration, they usually involve an array of cost implications for the manufacturer, whether explicit or implicit. It is, therefore, imperative that these costs be taken into account when assessing the most likely operating cost structure that can be anticipated, prior to 
taking a decision to decentralize, in this case, to an economic growth point within a National state. This is notwithstanding the concessions currently offered by the authorities, which must be carefully considered when determining the relative trade-offs with respect to centralization and decentralization.
The realities of these cost implications should also impel the authorities to take cognisance thereof with a view to formulating realistic and perceptive guidelines - based on empirically authenticated cost-benefit analysis which could assist manufacturers in their locational or relocational decision-making. 